\title{
Pathology and tissue tropism of natural West Nile virus infection in birds: a review
}

\author{
Virginia Gamino and Ursula Höfle*
}

\begin{abstract}
West Nile virus (WNV) is a globally distributed arthropod-borne flavivirus capable of infecting a wide variety of vertebrates, with birds as its natural reservoir. Although it had been considered a pathogen of little importance for birds, from the 1990's, and especially after its introduction in the North American continent in 1999, thousands of birds have succumbed to West Nile infection. This review summarizes the pathogenesis and pathology of WNV infection in birds highlighting differences in lesion and antigen distribution and severity among bird orders and families. Despite significant species differences in susceptibility to infection, WNV associated lesions and viral antigen are present in the majority of organs of infected birds. The non-progressive, acute or more prolonged course of the disease accounts for part of the differences in lesion and viral antigen distribution and lesion severity. Most likely a combination of host variables and environmental factors in addition to the intrinsic virulence and pathogenicity of the infecting WNV strain influence the pathogenesis of the infection.
\end{abstract}

\section{Table of contents}

1. Introduction

2. Etiology

3. Eco-epidemiology

4. Pathogenesis in birds

5. Pathology of natural WNV infection in birds

5.1. Central nervous system

5.2. Eye

5.3. Peripheral nervous system

5.4. Heart

5.5. Spleen and other lymphoid organs

5.6. Liver

5.7. Kidney

5.8. Lung

5.9. Gastrointestinal tract

5.10. Endocrine system

5.11. Gonads

5.12. Skeletal muscle

5.13. Skin

5.14. Bone marrow

6. Discussion and conclusion

7. Competing interests

8. Authors' contributions

9. Authors' information

* Correspondence: Ursula.hofle@uclm.es

SaBio Instituto de Investigación en Recursos Cinegéticos IREC,

(CSIC-UCLM-JCCM) Ronda de Toledo s/n, Ciudad Real 13005, Spain
10. Acknowledgements

11. References

\section{Introduction}

West Nile virus (WNV) is an arthropod-borne virus of the genus Flavivirus capable of infecting a wide variety of vertebrates, with birds as its natural reservoir [1]. It was first isolated in Uganda in 1937 from a woman with a febrile process [2]. During the 1960's WNV was one of the most widely distributed flaviviruses in humans, birds and mosquitoes in Africa, the Middle East and southwestern Europe, where it was considered a pathogen of little importance, causing subclinical infection or sporadic self-limiting outbreaks in horses and humans $[3,4]$. From the 1990's the frequency and severity of human infections as well as the number of cases in other vertebrates including companion, farm and wild animals has increased [5]. In Europe, WNV causes disease in horses and humans, and recently sporadic mortality events have been reported primarily in birds of prey [6-8]. In contrast, after its introduction into North America in 1999, where it caused one of the most important outbreaks in New York, thousands of birds, horses and humans have died of the disease $[9,10]$. Nowadays it is one of the most widely distributed flaviviruses in the world and an important public and animal health and conservation concern.

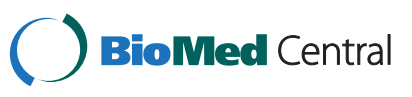

(c) 2013 Gamino and Höfle; licensee BioMed Central Ltd. This is an Open Access article distributed under the terms of the Creative Commons Attribution License (http://creativecommons.org/licenses/by/2.0), which permits unrestricted use, distribution, and reproduction in any medium, provided the original work is properly cited. 


\section{Etiology}

West Nile virus belongs to the genus Flavivirus of the family Flaviviridae. It has been serologically classified within the Japanese encephalitis antigenic group. The viral positive sense single-stranded RNA genome encodes a polyprotein which is translated into different structural (envelope protein E, membrane precursor protein prM and capsid protein $\mathrm{C}$ ) and non-structural (NS1, NS2a, NS2b, NS3, NS4a, NS4b, and NS5) proteins that play an important role in the viral host range, tissue tropism, viral replication and assembly, and host immune system stimulation [11-13]. Based on phylogenetic analysis, WNV strains have been grouped into seven genetic lineages [14] but there are two major lineages, lineage 1 and lineage 2. Lineage 1 is widespread and contains isolates from Europe, America, the Middle East, India, Africa and Australia [15,16]. Lineage 2 had originally only been isolated in Southern Africa and Madagascar but has recently also been detected in Europe [6,17-19]. In general lineage 1 viruses were considered to be more virulent than lineage 2 viruses, however it has been demonstrated that both lineages contain neuroinvasive phenotypes and some of the recent outbreaks in Europe, that also affect birds, have been caused by the latter $[6,18,20]$ (Table 1). Increased virulence of WNV strains has been associated to genetic and aminoacidic changes in structural and non-structural proteins. Substitution to a proline in position 249 of the non-structural protein NS3 has been associated with increased virulence in WNV lineage 1 strains in American crows (Corvus brachyrhynchos) and the same substitution has been detected in recent lineage 2 strains causing important outbreaks in Europe [15,21-24].

\section{Eco-epidemiology}

The virus is maintained in an enzootic ornitophilicmosquito-bird cycle [31]. Migratory birds are considered to play an important role in the local and long distance viral dispersal [32-35]. The most susceptible species to infection belong to the family Corvidae of the order Passeriformes such as the American crow, the blue jay (Cyanocitta cristata), the black-billed magpie (Pica hudsonia) or the fish crow (Corvus ossifragus) $[9,36]$. Some species of this order such as the American robin (Turdus migratorius) or the house sparrow (Passer domesticus) are also considered the main reservoir of WNV in urban areas of North America and Europe $[37,38]$. Other vertebrates susceptible to infection include amphibians, reptiles and mammals, among which the virus can be especially pathogenic for equids and humans. However, most of them are considered accidental or dead-end hosts as they rarely develop sufficient viremia to infect feeding mosquitoes [5,39]. Although WNV transmission in birds occurs primarily by mosquitoes of the genus Culex, transmission through infected prey or contaminated water consumption and horizontal contact transmission have also been documented $[36,40-43]$. The virus is maintained in a silent mosquito-bird cycle in natural habitats ("rural cycle") but can cause outbreaks in humans and horses when it is introduced in humanized habitats where mosquitoes with a wider host range are present, establishing an "urban cycle" [44]. In endemic areas wild bird infection usually starts in spring and early summer, mortality peaks from midsummer to early fall, and human and horse cases take place a few weeks after the onset of bird mortalities [45].

Before the 1990's WNV had been isolated in different parts of Europe, Asia and Africa but was rarely associated with clinical disease. Although some studies conducted in Africa in the 1950's underlined the role of birds as amplifying hosts and mortality was reported in host competence studies, especially in hooded crows (Corvus corone sardonius) [46], prior to $1997 \mathrm{WNV}$ was considered low-pathogenic for birds [47]. In 1998 a large outbreak took place in Israel with high mortality in birds, particularly in geese (Anser anser domesticus), and WNV was isolated from the brain of dead free-living storks (Ciconia ciconia) [48]. Currently, WNV is considered endemic in Europe [44]. Although viral circulation has been reported in many bird species, cases of encephalitis or mortality due to viral infection in wild birds have been sporadic [47] and observed mainly in raptors (Table 1). In North America WNV was detected for the first time in 1999 in New York [49] and since then it has caused thousands of bird deaths being detected in at least 326 bird species [50] (Table 2). WNV became endemic within ten years of its introduction into this continent [51]. The epidemiological behavior in North America, with an intense viral circulation, differs from the epidemiological behavior in other parts of the world including Europe, and the reasons remain largely unknown [44]. Viral phenotype, host heterogeneity in the area, vector abundance, feeding activity or host preference, and host susceptibility have been identified as possible modulating factors $[11,44,52-55]$. Host susceptibility to infection has been associated to geographic range, mating and breeding systems, body size, migratory behavior and to co-evolution with the virus or antigenically-related flaviviruses [56-60].

\section{Pathogenesis in birds}

Most of the information about the pathogenesis of WNV infection is derived from experimental studies done in mammals, mainly rodents. In these hosts, after mosquito blood-feeding, WNV replicates in the skin and is transported by Langerhans dendritic cells to draining lymph nodes. There the virus replicates and primary 
Table 1 Bird species found dead or with symptoms of encephalitis in Europe in which the presence of WNV has been evidenced by real time RT-PCR or by virus isolation

\begin{tabular}{|c|c|c|c|c|c|c|}
\hline Year & Country & Order & Family & Species & Lineage & Ref \\
\hline \multirow[t]{2}{*}{$2001-2004$} & Spain & Falconiformes & Accipitridae & Spanish imperial eagle & 1 & {$[7]$} \\
\hline & & & & (Aquila adalberti) & & \\
\hline \multirow[t]{2}{*}{2003} & Hungary & Anseriformes & Anatidae & Domestic goose & 1 & {$[6,25]$} \\
\hline & & & & (Anser anser domesticus) & & \\
\hline \multirow[t]{6}{*}{2004} & Hungary & Falconiformes & Accipitridae & Goshawk & 2 & {$[6,26]$} \\
\hline & & & & (Accipiter gentilis) & & \\
\hline & France & Passeriformes & Corvidae & Common magpie & 1 & [27] \\
\hline & & & & (Pica pica) & & \\
\hline & & & Passeridae & House sparrow & & \\
\hline & & & & (Passer domesticus) & & \\
\hline \multirow[t]{3}{*}{2005} & Hungary & Falconiformes & Accipitridae & Goshawk & 2 & {$[20,28]$} \\
\hline & & & & Sparrow hawk & & \\
\hline & & & & (Accipiter nisus) & & \\
\hline \multirow[t]{4}{*}{2007} & Spain & Falconiformes & Accipitridae & Golden eagle & 1 & {$[28]$} \\
\hline & & & & (Aquila chrysaetos) & & \\
\hline & & & & Bonelli's eagle & & \\
\hline & & & & (Aquila fasciata) & & \\
\hline \multirow[t]{20}{*}{2008} & Austria & Falconiformes & Accipitridae & Sparrow hawk & 2 & {$[20,28]$} \\
\hline & & & & (Accipiter nisus) & & \\
\hline & & & & Goshawk & & \\
\hline & & & & (Accipiter gentilis) & & \\
\hline & & & Falconidae & Gyrfalcon & & \\
\hline & & & & (Falco rusticolus) & & \\
\hline & & Psittaciformes & Strigopidae & Kea & & [28] \\
\hline & & & & (Nestor notabilis) & & \\
\hline & Italy & Charadriiformes & Laridae & Herring gull & 1 & [29] \\
\hline & & & & (Larus argentatus) & & \\
\hline & & Columbiformes & Columbidae & Pigeon & & \\
\hline & & & & (Columba livia) & & \\
\hline & & Passeriformes & Corvidae & Common magpie & & \\
\hline & & & & (Pica pica) & & \\
\hline & & & & Carrion crow & & \\
\hline & & & & (Corvus corone) & & \\
\hline & & & & Eurasian jay & & \\
\hline & & & & (Garrulus glandarius) & & \\
\hline & & Suliformes & Phalacrocoracidae & Great cormorant & & \\
\hline & & & & (Phalacrocorax carbo) & & \\
\hline \multirow[t]{2}{*}{2009} & Austria & Falconiformes & Accipitridae & Goshawk & 2 & [20] \\
\hline & & & & (Accipiter gentilis) & & \\
\hline \multirow[t]{2}{*}{2011} & Italy & Columbiformes & Columbidae & Collared dove & 2 & [18] \\
\hline & & & & (Streptopelia decaocto) & & \\
\hline \multirow[t]{2}{*}{2012} & Italy & Falconiformes & Accipitridae & Goshawk & 2 & [30] \\
\hline & & & & (Accipiter gentilis) & & \\
\hline
\end{tabular}


viremia and peripheral organ dissemination take place [61]. On the contrary, the exact mechanism and sites of WNV replication in avian hosts are still not well understood. It is supposed that, as in mammals, it replicates locally at the inoculation site and is rapidly distributed to all organ systems [62]. However, it has been demonstrated that the virus can be detected in the blood as early as 30-45 min after the mosquito feeding period, suggesting that in birds local replication is not necessary for the primary viremia [63]. In general, WNV can be isolated from the blood of infected birds at one day post-infection (dpi) (one day later in less susceptible species such as chicken or turkeys or in the case of oral infection) $[34,64,65]$. Viremia can peak as early as 2-3 dpi in geese and some Passeriformes such as crows and jays, or 4-6 dpi in raptors, owls and chicken [43,64-67]. Mean peak viremia is higher in those birds that finally

\section{Table 2 Bird orders and families from North America in which mortality due to WNV infection has been} demonstrated

\begin{tabular}{|c|c|}
\hline ORDER & FAMILY \\
\hline Anseriformes & Anatidae \\
\hline Apodiformes & Apodidae, Trochilidae \\
\hline Caprimulgiformes & Caprimulgidae \\
\hline Casuariiformes & Dromaiidae \\
\hline Charadriiformes & Charadriidae, Laridae \\
\hline Ciconiiformes & $\begin{array}{l}\text { Ardeidae, Cathartidae, Ciconiidae, } \\
\text { Threskiornithidae }\end{array}$ \\
\hline Columbiformes & Columbidae \\
\hline Coraciiformes & Alcedinidae, Bucerotidae \\
\hline Cuculiformes & Cuculidae \\
\hline Falconiformes & Accipitridae, Falconidae \\
\hline Galliformes & Numididae, Odontophoridae, Phasianidae \\
\hline Gaviiformes & Gaviidae \\
\hline Gruiformes & Aramidae, Gruidae, Rallidae \\
\hline Musophagiformes & Musophagidae \\
\hline Passeriformes & $\begin{array}{l}\text { Bombycillidae, Cardinalidae, Cinclidae, Corvidae, } \\
\text { Emberizidae, Estrildidae, Fringillidae, Icteridae, } \\
\text { Laniidae, Mimidae, Paridae, Parulidae, Passeridae, } \\
\text { Sittadae, Sturnidae, Thraupidae, Troglodytidae, } \\
\text { Turdidae, Vireonidae }\end{array}$ \\
\hline Pelecaniformes & Pelecanidae, Phalacrocoracidae \\
\hline Phoenicopteriformes & Phoenicopteridae \\
\hline Piciformes & Picidae \\
\hline Podicipediformes & Podicipedidae \\
\hline Psittaciformes & Aratingidae, Cacatuidae, Psittacidae \\
\hline Sphenisciformes & Spheniscidae \\
\hline Strigiformes & Strigidae, Tytonidae \\
\hline Struthioniformes & Struthionidae \\
\hline Tinamiformes & Tinamidae \\
\hline
\end{tabular}

succumb to the disease [38]. WNV can be detected in the blood until day 6-7 pi in geese, passerines and owls and up to $10 \mathrm{dpi}$ in raptors and turkeys [40,66-69]. Little is known about innate avian host defenses against WNV infection. In mammals, this includes IFN production, complement activation, phagocytosis and cytotoxicity, with the participation of macrophages, neutrophils, NK cells and $\gamma \delta$ T cells $[61,70]$. WNV infects all major organ systems and a wide variety of individual cell types. The targeting of cells of the mononuclear phagocytic system may play an important role in the pathogenesis in infected birds, as the virus can replicate within these cells and disseminate to a wide variety of tissues [64,71]. As early as $1 \mathrm{dpi}$ WNV can be detected in the spleen of crows and one day later it is widely distributed. In this species the highest viral titer in tissues can be reached on day $4 \mathrm{pi}$, decreasing from day 5 pi [64]. On the contrary in falcons and owls maximum viral titer in tissues can be delayed until day 7-8 pi, decreasing from day 9 $\mathrm{pi}$, and while in falcons the virus remains detectable on day $14 \mathrm{pi}$, it can be totally cleared from most tissues of owls [42,66,72].

Flaviviruses have evolved different strategies that modulate the host immune response [73] and depending on the effectiveness of this response and, therefore, the level of viremia, WNV can reach the central nervous system (CNS). While WNV can be detected in the brain of crows as early as $2 \mathrm{dpi}$, in owls it may not be present before $5 \mathrm{dpi}[64,66]$. In the former maximum viral titer in this tissue can be reached on day 4 pi while this may not take place in the latter until day 8 pi or until $14 \mathrm{dpi}$ in falcons $[64,66,72]$. The mechanisms by which WNV crosses the blood-brain barrier and reaches the CNS remain unknown. Some authors have suggested that TNF$\alpha$ mediated change in endothelial cell permeability may facilitate its entry, at least in mammals [74]. Other mechanisms proposed are the infection of or passive transport through the endothelium or epithelial cells of the choroid plexus [75], direct axonal retrograde transport from olfactory or motor neurons [76,77] or transport by infected immune cells [78]. In birds, WNV detection in endothelial cells by immunohistochemistry (IHC) and the presence of perivascular inflammatory infiltrates $[79,80]$ may indicate that WNV reaches the CNS via the blood stream and infects endothelial cells, although viral transport through infected immune cells may also be probable [64].

The development of clinical disease is caused by the invasion of the CNS and/or other major organs such as the liver, spleen, kidney and heart [71]. In most cases, clinical signs appear approximately on 5 dpi in experimentally WNV infected birds, but may be absent both in experimental and natural infections [36,42,81-84]. Unspecific clinical signs include depression, anorexia, 
dehydration and ruffled feathers. In more than $60 \%$ of infections convulsions are present, approximately in 30\% appear ataxia, abnormal head posture and head movements, and in up to $20 \%$ tremors, uncoordinated flight, paresis and disorientation are observed [71,82,85-89]. The development of impaired vision and blindness is common in raptors and owls [89-91]. Long-term sequelaes have been detected in long-lived birds such as raptors, in which relapses of neurologic signs, feather pulp abnormalities and abnormal molt can persist up to 4 years [92], and may have a negative impact on the longevity of these species $[42,92]$.

Systemic infection of the host also activates the adaptive immune response that includes $\mathrm{B}$ and $\mathrm{T}$ cell activation and antibody production [61,70]. In most bird species seroconversion can first be detected between 46 dpi [64,84] and neutralizing antibodies, at least in some species, persist for longer than a year and can be transferred from adult females to their progeny [93-96]. In mice it has been indicated that $\mathrm{CD}^{+}$and $\mathrm{CD}^{+} \mathrm{T}$ lymphocytes combined with antibodies and chemokines are essential for viral clearance from the CNS and peripheral organs [97]. In birds it has been demonstrated that the virus can persist in different organs such as the spleen, kidney, eye, brain or the skin [36,98-101]. Wheeler et al. [98] demonstrated that viral persistence in naturally infected Passeriformes can last for 4 months extending to up to 6 months in experimentally infected birds. Viral persistence consequences for the avian host are still not clear [98] but it can play an important role in viral overwintering and mosquito infection in case of host immune defenses impairment and viremia recrudescence [101-103].

In case of host defense failure, death often occurs within $24 \mathrm{~h}$ or two to four days after the onset of clinical signs in experimentally or naturally infected birds, respectively $[25,26,36,83]$. Sometimes death is not directly related to WNV associated tissue lesions but to concurrent disease such as trauma or bacterial, fungal or parasitic infections $[7,42,88,92]$.

The outcome of WNV infection and development of lesions and disease in individual birds depend mainly on viral and host factors. Glycosylation in the $\mathrm{E}$ protein of WNV has been demonstrated to increase peripheral viremia and virulence for birds and neuroinvasiveness in rodents [104,105]. Brault et al. [21] experimentally demonstrated that a $\mathrm{T}_{249} \mathrm{P}$ NS3 substitution in the WNV NY99 strain increased virulence for American crows. However, this substitution appears not to have the same effect for some other North American bird species and an experimental study has shown that this substitution alone in European WNV strains does not necessarily lead to an increased virulence for susceptible European birds [84]. Papa et al. [23] related the $\mathrm{H}_{249} \mathrm{P}$ NS3 substitution to the increased virulence of the lineage 2 WNV strain that caused the outbreak in humans in Greece in 2010 [106], but the role of this substitution in the virulence for birds is not clear, as lineage 2 strains that have caused mortalities in birds do not show this change $[18,23,30]$. Therefore, the presence of other genetic markers of virulence could be implicated [22,107].

The existence of natural infections of goshawks (Accipiter gentilis) by either WNV lineage 1 and 2 strains allows comparison of the associated pathology. In both cases viral cellular and tissue tropism is similar but lesion localization and nature slightly differ. Thus for example splenic lymphoid depletion, nephritis and hepatitis present in lineage 2 infected goshawks are not described in those infected by lineage 1 which in change have hepatic and myocardial necrosis that are not described in those infected by lineage $2[20,26,91]$.

Another determinant factor is the ability of the WNV strain to replicate at the high corporal temperature of the avian host, as has been demonstrated for the WNV NY99 genotype [108]. Moreover, viral inoculation dose should not be forgotten, although dose-dependent pathological differences are not always evidenced in experimental infections [67]. Finally, infection route can influence pathogenicity of WNV infections, as some authors have indicated that in orally infected birds tissue lesions are less severe and the incidence of clinical signs or mortality is lower than in those subcutaneously infected $[36,42]$. Bird species is an important host factor that influences the pathogenesis of WNV infection, as has been demonstrated by numerous authors [36,71,79]. Also, the immune status of the host plays an essential role in the pathogenesis, as it determines the capacity of the host to clear the virus [61]. It can be modulated by the presence of previous immunity against the virus or cross immunity against antigenically-related flaviviruses, the presence of concurrent diseases, the influence of hormonal factors and stress, as well as age [56,83,109-112]. Age not only determines the maturity of the immune system but also the expression of cellular receptors important for viral entry and intracellular factors that participate in the pathogenesis of the disease [113]. Finally, it has been demonstrated in avian and rodent models that genetic factors influence host susceptibility to flaviviral infections $[114,115]$.

\section{Pathology of natural WNV infection in birds}

The pathology of natural WNV infection in birds has been documented in more than 57 species of at least 13 families and 10 orders.

Because of the wide cellular and tissue tropism of WNV, there are no pathognomonic macroscopic lesions. Bird species with a low susceptibility to WNV infection such as chicken may have no observable macroscopic 
lesions at necropsy [65], and those highly susceptible such as crows or jays will die rapidly after a short incubation period and may have few acute or no observable lesions $[80,81]$. In contrast, birds that survive longer will have more pronounced macroscopic lesions, that may be chronic in the case of individuals that survive days to months [79,91]. Emaciation, dehydration, multiorgan hemorrhages, petechiae and congestion are the most characteristic macroscopic changes, but also splenomegaly, hepatomegaly, myocardial pallor and pale mottling in the liver, spleen or kidney. Cerebral atrophy and malacia can be observed in raptors $[42,71,91]$.

In the vast majority of bird families, microscopic lesions due to WNV infection are predominantly found in the CNS, heart, kidney, spleen and liver (Table 3). Pathological changes can be the result of the direct effect of the virus or secondary to the host inflammatory response $[113,116,117]$. Lymphoplasmacytic and histiocytic infiltrates, cellular degeneration and necrosis, and hemorrhages are the main microscopic findings. However, there are differences in antigen and microscopic lesion severity and distribution pattern depending on the species infected or the dpi the analyzed individual died [1] (Table 3 and Figure 1). Highly susceptible species such as crows and jays usually have large amounts of virus in the blood and widely distributed in major organs. Microscopic changes in these cases are acute with minimal inflammatory reaction and can be absent in the CNS $[64,80,118]$. In contrast, birds that survive longer such as raptors and owls may develop chronic lesions that can be also found in the CNS $[42,91]$.

\subsection{Central nervous system}

CNS lesions can appear on 8-9 dpi in falcons and owls, increasing their severity during the course of infection, and can be maintained chronically [42,66,72]. In the chicken, the appearance of lesions can be delayed until 21 dpi [65]. Lymphoplasmacytic and histiocytic meningoencephalitis characterized by gliosis, perivascular cuffing and glial nodules is the main microscopic finding. This inflammation is usually present in the molecular layer of the cerebellum and in some cases also in the cerebrum, mesencephalon and medulla oblongata. Neuronal necrosis and degeneration are usually found in raptors [42] and owls [119]. Vasculitis is detected in red-tailed hawks (Buteo jamaicensis), yellow-billed magpies (Pica nuttalli) and house sparrows $[42,120,121]$ and hemorrhages are observed in guanay cormorants (Phalacrocorax bougainvillea), turkeys and owls [71,90,122] (Table 3). WNV antigen is usually detected by IHC in the CNS. Cells showing antigen labeling include neurons (including Purkinje cells) and glial cells as well as other inflammatory cells and vascular endothelial cells.

\subsection{Eye}

The eye is not routinely microscopically studied due to the difficulty of obtaining sections suitable for interpretation. However, it has been more closely examined in raptors and owls, probably because of the importance of vision in these species. Moderate to marked lymphoplasmacytic and histiocytic inflammatory infiltrates, disarray of the retinal pigmented epithelial cell layer and retinal cell necrosis and mineralization have been described in naturally WNV infected hawks [117]. Birds of the order Psittaciformes and Strigiformes only show inflammatory infiltrates that are mainly detected in the conjunctiva, iris, choroid, pecten and retina $[90,123]$ (Table 3). WNV antigen is detected in different cells of the retina and in inflammatory infiltrating cells. Although Wünschmann et al. [80] described the presence of WNV antigen in endothelial cells of the pecten and choroid in the eye of infected American crows, they did not describe associated lesions in this species. In contrast, WNV antigen presence has not been documented in the eye of Psittaciformes [123].

\subsection{Peripheral nervous system}

WNV related lesions in the peripheral nervous system have only been described in raptors and owls [119]. Mononuclear or mixed inflammation is usually present in the sciatic nerve and in the myenteric, proventricular and ventricular ganglia (Table 3 ). Neuronal positivity can be detected by IHC.

\subsection{Heart}

Myocardial lesions may not be detected in falcons until $14 \mathrm{dpi}$, but appear earlier in owls (8 dpi) and crows (6 dpi) [64,66,72]. Lymphoplasmacytic and histiocytic myocarditis with myocardial necrosis, degeneration, mineralization or fibrosis and hemorrhages are the main microscopic findings. Vasculitis can be seen in blue jays and American kestrels (Falco sparverius) [42,118] (Table 3). Cardiomyocytes, inflammatory and endothelial cells, and smooth muscle cells of arteries usually show immunostaining. Although the heart is usually affected in WNV infected birds, Anseriformes rarely have lesions in this tissue, even though viral antigen is demonstrated by IHC [71].

\subsection{Spleen and other lymphoid organs}

Splenic lesions can appear as early as $2 \mathrm{dpi}$ in jays and crows, increasing in severity as infection progresses [64] but in falcons they may not be prominent until $7 \mathrm{dpi}$ [72]. In this organ, lymphoid necrosis or apoptosis with fibrin deposition and hemosiderosis are consistently observed. Hemorrhages are described in ducks, guanay cormorants, and black-crowned night heron (Nycticorax nycticorax) [71] and lymphoid depletion in goshawks 
Table 3 Distribution of specific lesions in tissues of naturally WNV infected birds

\begin{tabular}{lccc}
\hline Order* & ANSE & CHAR & CICO \\
Family & ANAT & LARI & ARDE \\
\hline Reference & {$[25,71,124]$} & {$[71]$} & {$[71]$} \\
TISSUE/Lesion & & & \\
BRAIN & & & \\
Neuronal necrosis-degeneration & + & - & ND \\
Neuronal vacuolization & - & + & ND \\
Meningeal inflammatory infiltrates & + & - & ND \\
Gliosis & + & + & ND \\
Perivascular cuffs & + & + & ND \\
Glial nodules & + & + & ND \\
Vasculitis & - & - & ND \\
Hemorrhage & - & - & ND
\end{tabular}

\section{SPINAL CORD}

Neuronal necrosis-degeneration

Inflammatory infiltrates

$$
+\quad \text { ND ND }
$$

EYE

Retinal cell necrosis

Inflammatory infiltrates

\section{PERIPHERAL NERVOUS SYSTEM}

Inflammatory infiltrates

HEART

Myofibril necrosis

Myocytolisis-mineralization

Inflammatory infiltrates

Vasculitis

Hemorrhage

SPLEEN

Lymphoid cell necrosis/apoptosis

Fibrin deposition

Lymphoid cell depletion

Hemosiderosis

Hemorrhage 
Table 3 Distribution of specific lesions in tissues of naturally WNV infected birds (Continued)

\section{LIVER}

Hepatocyte necrosis

Kupffer cell necrosis

Inflammatory infiltrates

Vasculitis

\section{LIVER}

Biliary duct hyperplasia

Hemosiderosis

Hemorrhage

\section{KIDNEY}

Tubular epithelial cell necrosis

Glomerular cell necrosis

Inflammatory infiltrates

Vasculitis

Hemorrhage

LUNG

Cellular necrosis

Inflammatory infiltrates

Vasculitis

Edema

\section{GASTROINTESTINAL TRACT}

Enterocyte necrosis

Intestinal crypt cell necrosis

Inflammatory infiltrates

Hemorrhage

\section{ENDOCRINE SYSTEM}

Pancreatic acinar cell necrosis

Pancreatic inflammatory infiltrates Adrenal gland cell necrosis

Adrenal inflammatory infiltrates

Thyroid gland cell necrosis

Thyroid inflammatory infiltrates

$\begin{array}{lll}- & N D & N D \\ - & N D & N D \\ - & N D & N D \\ - & N D & N D\end{array}$


Table 3 Distribution of specific lesions in tissues of naturally WNV infected birds (Continued)

\section{OTHER LYMPHOID ORGANS}

Bursal lymphoid cell atrophy-apoptosis

Thymic lymphoid cell necrosis

\section{GONADS}

Cellular necrosis

Inflammatory infiltrates

\section{SKELETAL MUSCLE}

Myofibril degeneration-necrosis

Inflammatory infiltrates

Fibrosis

SKIN

Inflammatory infiltrates

\section{BONE MARROW}

Cellular necrosis

$\begin{array}{lll}- & \text { NT } & \text { NT } \\ - & \text { NT } & \text { NT } \\ + & \text { NT } & \text { NT }\end{array}$

$+$

NT
NT
NT

NT
NT

NT

$\begin{array}{llllll}\text { NT } & - & \text { NT } & \text { NT } & \text { ND } & + \\ \text { NT } & + & \text { NT } & \text { NT } & \text { ND } & + \\ \text { NT } & \text { NT } & \text { NT } & \text { NT } & - & +\end{array}$

$+$

NT

NT

ND ND

$-$

$-\quad N D$

NT

$\begin{array}{llllll}\mathrm{ND} & \mathrm{NT} & \mathrm{ND} & \mathrm{ND} & - & +\end{array}$

ND ND ND

$-\quad$ ND

NT

ND NT ND ND

$+$

$\begin{array}{lll}N D & N T & N T \\ N D & N T & N T\end{array}$

$+$

$-\quad-$

ND

$\begin{array}{lllll}\text { NT NT NT NT } & + & +\end{array}$

ND

NT NT NT NT

$\begin{array}{lll}\text { NT NT NT NT } & \end{array}$

$+$

$+$

$-\quad-$

ND

$\begin{array}{lll}\text { NT } & \text { NT }\end{array}$

ND NT NT NT

NT $\quad-$

$\begin{array}{lll}\text { NT NT NT NT } & \text { NT }\end{array}$

ND

ND

Hypercellularity

$\begin{array}{llll}\text { NT } & \text { NT } & \text { NT } & \text { ND }\end{array}$

NT $\quad+$

$\begin{array}{lllll}N T & N T & N T & N T & N D\end{array}$

ND

*ANSE Anseriformes, CHAR Charadriiformes, CICO Ciconiiformes, FALC Falconiformes, GALL Galliformes, PASS Passeriformes, PELE Pelecaniformes, PHOE Phoenicopteriformes, PSIT Psittaciformes, STRI Sitrigiformes. - ANAT Anatidae, LARI Laridae, ARDE Ardeidae, ACCI Accipitridae, FALC Falconidae, PHAS Phasianidae, CORV Corvidae, LANI Laniidae, PASS Passeridae, PHAL Phalacrocoracidae, PHOE Phoenicopteridae, PSIT Psittacidae, STRI Strigidae.

ND: No described lesion. Tissues that were taken during necropsy but for which there are no lesions described.

NT: Tissue not tested. Tissue not analyzed in the necropsy.

+ Lesion present. Lesion described by at least one author for the tissue.

- Lesion absent. Lesion stated as absent or not specifically described by any author for the tissue. 


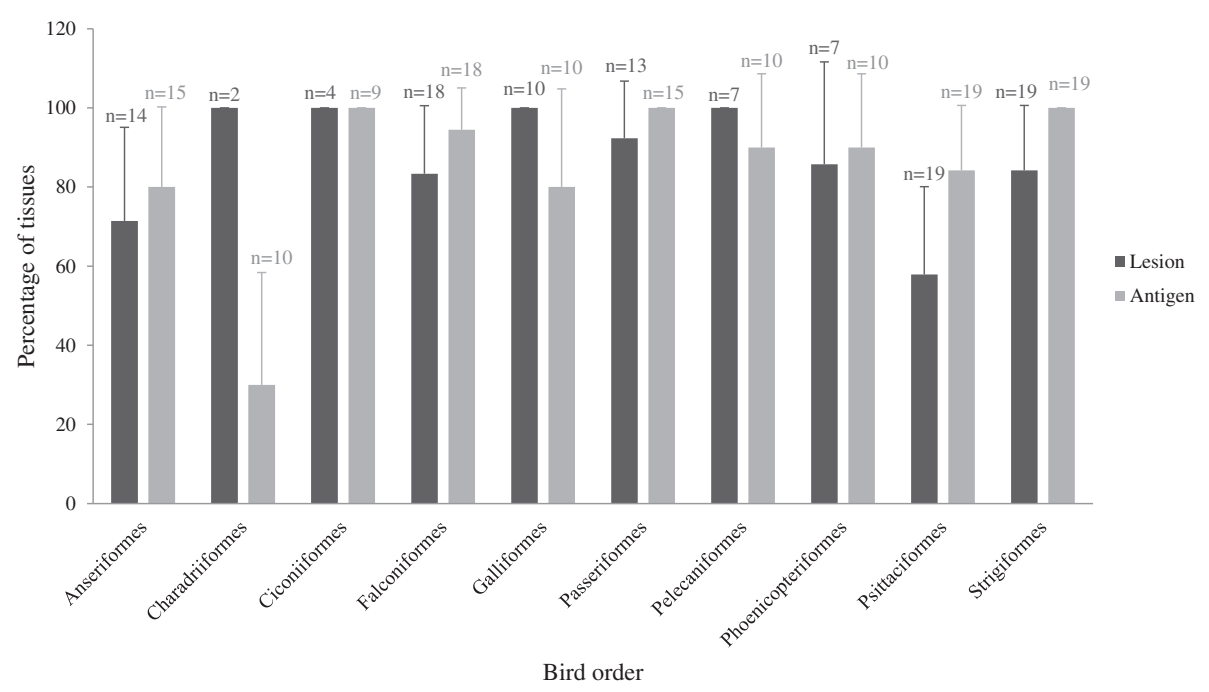

Figure 1 Lesion extension and antigen distribution among examined tissues in WNV infected bird orders as reported in the reviewed literature. Each column represents the percentage of tissues collected $(n)$ in which lesions or antigen is present.

and owls [26,58] (Table 3). Viral antigen is detected in dendritic cells/macrophages and smooth muscular cells of arterioles. Necrosis can be found in bursal and thymic lymphoid cells $[119,124]$ but these tissues have only been analyzed in some naturally WNV exposed birds, most probably because they are only present in juvenile birds (Table 3).

\subsection{Liver}

Similarly to the spleen, hepatic lesions can be found in crows as early as 3 dpi and increase in severity during progress of the infection [64]. In owls and falcons on day 5 pi these lesions are mild changing to severe by day $14 \mathrm{pi}$ [66,72]. Lymphoplasmacytic and histiocytic hepatitis as well as coagulative hepatocyte necrosis are the most frequent lesions. Hemorrhages in goshawks and blue jays [26,118], biliary duct hyperplasia in northern bald eagles (Haliaeetus leucocephalus alascanus) and Chilean flamingos (Phoenicopterus chilensis) [71], and vasculitis in American kestrels can also be found [42] (Table 3). Birds that show hemosiderosis in the spleen usually also have it in the liver $[119,120,122]$ (Table 3$)$. WNV antigen is mainly seen in hepatocytes and Kupffer cells. Anseriformes do not show lesions [25] but WNV antigen is detected by IHC.

\subsection{Kidney}

Renal lesions can be moderate on 6 dpi in crows [62] and 9 dpi in owls [66] but may not become apparent until $14 \mathrm{dpi}$ in falcons [72]. Lymphoplasmacytic and histiocytic interstitial nephritis and tubular epithelial cell degeneration and/or necrosis are detected in most WNV infected birds. Glomerular cell degeneration and/or necrosis are described in birds of the order Psittaciformes and Strigiformes $[87,90]$ and so are hemorrhages in ducks [124] and vasculitis in American kestrels [66] (Table 3). IHC demonstrates WNV antigen in tubular and collecting duct epithelial cells, glomerular cells, infiltrating inflammatory cells, interstitial fibroblasts and, less frequently, in endothelial cells.

\subsection{Lung}

WNV antigen labeling and associated lesions are not usually described in the lung or if present they are mild. Lymphohistiocytic inflammatory infiltrates have occasionally been described and interstitial edema and necrosis can also be found. In naturally WNV infected Anseriformes and Psittaciformes pulmonary lesions have not been documented [123,124] (Table 3). Viral antigen is detected mainly in inflammatory cells although it can also be found in epithelial cells of the air capillaries.

\subsection{Gastrointestinal tract}

Lesions in the gastrointestinal tract are mainly described in the proventriculus, ventriculus and intestines with enterocyte and intestinal crypt cell necrosis, lymphoplasmacytic and histiocytic infiltrates, and proventricular gland and ventricular hemorrhages as main microscopic findings. In owls, but even less so in goshawks, lesions in the gastrointestinal tract are rarely found or if present changes are mild $[26,82]$ (Table 3). Viral antigen is usually detected in enterocytes and intestinal crypt cells, inflammatory cells and smooth muscle cells of the lamina muscularis. 


\subsection{Endocrine system}

Lymphoplasmacytic and histiocytic pancreatitis and acinar cell necrosis are present in most species (Table 3). WNV antigen is detected in exocrine cells. Adrenalitis has been described in different bird species but adrenal gland cell necrosis has only been documented in Psittaciformes [87] (Table 3). Viral antigen is present in both cortical and medullary cells. Thyroid gland has rarely been analyzed in the available studies but follicular cell necrosis has been described in ducks [124] and thyroiditis in goshawks [91] (Table 3). Viral antigen in follicular cells has only been described in owls [90] and goshawks [26,91].

\subsection{Gonads}

WNV associated lesions in gonads have only been documented in owls in which the authors described oophoritis, epididimitis and necrosis of granulosa cells, oocytes and seminiferous tubular cells [90] (Table 3). Viral antigen has been detected in different species in oocytes, theca and granulosa cells, stromal cells, seminiferous tubule cells and infiltrating inflammatory cells.

\subsection{Skeletal muscle}

In the skeletal muscle WNV infection can produce myositis, myofibril degeneration, necrosis and fibrosis (Table 3). IHC shows viral antigen in myofibers but this is not consistently observed [123].

\subsection{Skin}

Lymphocytic dermatitis has only been described in WNV infected Psittaciformes [87] (Table 3). Viral antigen is detected in keratinocytes of the basal layer of the epidermis, fibrocytes and macrophages of the dermis and subcutis, interstitial cells and epithelial cells of the feather pulp. Although in raptors and owls skin lesions are not described, viral antigen is usually detected [91].

\subsection{Bone marrow}

Cellular necrosis in American crows [80] and hypercellularity in turkeys [122] are the only lesions that have been described in the bone marrow (Table 3). WNV antigen can be detected in hematopoietic cells.

Despite all the cited differences among bird orders, families or even species, lesions and viral antigen are described in the majority of organs in WNV infected birds (Figure 1).

\section{Discussion and conclusion}

West Nile virus, a pathogen considered of little importance for birds before the 1990's [47], is nowadays one of the most widely distributed arboviruses in the world that causes thousands of bird deaths, with a locally significant impact on populations of native species in North America $[9,125]$.

In this work we have reviewed the pathogenesis of WNV infection in experimentally infected birds and the main pathologic changes that have been described in natural infections. The information that has been reviewed indicates on one hand that in most infected birds the virus first appears in the spleen after which it spreads rapidly to other organs such as the kidney, lung, heart and liver, reaching later the CNS. However, tissue distribution takes place earlier in bird species highly susceptible to the infection such as Passeriformes and later in less susceptible species such as Falconiformes, Galliformes or Strigiformes. On the other hand, the reviewed information indicates that most infected birds that show clinical disease and some of those that die without previous clinical manifestations have macroscopic and/or microscopic lesions, but that there may be differences in their distribution and severity between species even within the same family. Accordingly, considerable differences exist among species in expression of clinical disease that are not always clearly related to the severity and distribution of lesions. For example, nervous clinical signs do not always correlate with the pathological findings in the brain such as neuronal necrosis.

Acute lesions such as encephalitis and hemorrhages in different tissues are consistently found in the vast majority of the described bird families. Hemorrhagic fever associated to WNV infection has mainly been described in humans $[126,127]$ in which hemorrhages are thought to be related to direct or indirect microvascular damage [127]. Thus similarly, the vasculitis and endothelial WNV antigen found in some bird species could explain the presence of blood extravasation. A study on human pathogenic flaviviruses has associated sequence signatures in the envelope protein of the virus with the primary syndrome that they produce (encephalitis or hemorrhagic disease) [128], but envelope protein sequence is not available for most WNV strains that infected the birds from which lesion descriptions exist. One lesion that is not consistently found in every bird family or even in different species within families is hemosiderosis in the spleen and liver. Avian hepatic hemosiderosis has been observed in relation to iron overload in captive wild forest birds but is also frequently associated to hemolytic processes in acute infectious disease [129]. Although Passeriformes develop necrosis and mild inflammation in the heart, spleen, liver or kidney, they show only mild encephalitic lesions and neuronal necrosis is absent $[71,80,121]$. This may be related to the higher susceptibility of this order to WNV infection leading to rapid viral distribution and host death that does not allow development of encephalic 
lesions [118]. The absence of encephalitis in juvenile chukar partridges (Alectoris chukar) and Impeyan pheasants (Lophophorus impeyanus) [83] could have the same explanation. In contrast, neuronal degeneration, necrosis and phagocytosis are well documented in Strigiformes and Falconiformes, potentially because the course of the disease in these species is more prolonged. The detection of WNV antigen or genome by IHC or real time RT-PCR in a particular tissue, even when there are no observable macroscopic or microscopic lesions, or the apparent absence of viral antigen immunolabeling although microscopic related lesions are present, may have the same underlying cause $[90,118]$. Thus, lesion description and viral antigen detection should be considered together in order to enable us to understand the pathogenesis of WNV infection in a particular host.

Many pathologic differences are related to the time post-infection the animal died which is related to its susceptibility to infection and immune capacity at the time the virus is inoculated, as well as the infection route (oral vs. mosquito), the infective dose and the virulence of the infecting virus. Looking for example at the description of Lopes et al. [79], species specific factors are evident as in this case the infecting virus, route and dose were probably very similar. Based upon the evaluated information, apparently there are species in which the individuals respond early and strongly to the infection clearing the virus rapidly, suffering thus only mild microscopic lesions and causing only few individuals to succumb to the disease [72]. On the contrary, other species potentially mount a weak immune response of late onset that leads to high tissue viral loads and death due to the severity of tissue lesions during the first general viremia $[62,68]$. Finally, there is a third group of species which maintains low levels of viral replication that leads to chronic infection which can finally produce host death or long-term sequelaes [42]. Nevertheless, it is important to consider that the literature about the pathology of natural WNV infection in birds is limited to a number of species that may not necessarily reflect the complete host spectrum of species affected by natural disease. Thus, the information is unbalanced, meaning that the absence of lesions in certain tissues in any particular bird species could be related to the limited number of studies available. The reason why most studies about the pathology of WNV infection have been carried out in raptors and owls may be related to the higher visibility of dead or clinically affected animals of these species in the field. Furthermore, these animals are frequently maintained in facilities such as zoos or rehabilitation centers where they are observed daily allowing to perform necropsies of fresh carcasses in case of death. Additionally, studies in corvids in the US are probably driven by the magnitude of mortalities in these species and their visibility for the public as they are relatively abundant in urban and suburban areas. The lack of information about WNV infection pathology in other species could be related to the lack of fresh carcasses that enable a detailed pathological description.

Certain bird species considered resistant to the disease in the field such as the red-legged partridge (Alectoris rufa) develop lesions and succumbed to the disease in experimental studies [84]. Therefore, it is important to consider that lesion and viral antigen distribution between experimentally and naturally infected bird species is probably different, and that numerous contributing factors in the field are generally not reproduced under experimental conditions.

In conclusion, differences in pathology of WNV infection in different bird species are most probably related to a combination of host and environmental factors in addition to the intrinsic virulence and pathogenicity of the infecting virus strain. The non-progressive, acute or more prolonged course of the disease accounts for part of the differences in the distribution of lesions and viral antigen and in the severity of lesions. Finally, although experimental infections cannot completely reproduce field situations, they can increase our understanding of pathologic pathways and help in the identification of key factors that influence the outcome of an infection in a given host.

\section{Competing interests}

The authors declare that they have no competing interests.

\section{Authors' contributions}

$\mathrm{UH}$ proposed the subject, wrote the outlines and reviewed and edited the paper, VG compiled the information, wrote and edited the paper. Both authors agreed on the final version of the manuscript.

\section{Authors' information}

VG is a grant student in avian pathology at IREC and has a special interest in flavivirus infections. Her supervisor UH investigates and teaches on infectious diseases in wild birds.

\section{Acknowledgements}

This review is part of the work supported by grant AG2008-02504GAN funded by the Spanish Ministry for Science and Innovation. V. Gamino (323/ 09) is a research fellow supported by the regional government of Castilla La Mancha (JCCM). We acknowledge F. Ruiz-Fons for critically reviewing an early draft of the paper.

Received: 6 January 2013 Accepted: 24 April 2013

Published: 3 June 2013

\section{References}

1. McLean R, Ubico S: Arboviruses in Birds. In Infectious Diseases of Wild Birds. Edited by Thomas N, Hunter D, Atkinson C. lowa: Blacwell Publishing; 2007:17-62.

2. Smithburn KC, Hughes TP, Burke AW, Paul JH: A neurotropic virus isolated from the blood of a native of Uganda. Am J Trop Med Hyg 1940, 20:471-492.

3. Dauphin G, Zientara S, Zeller H, Murgue B: West Nile: worldwide current situation in animals and humans. Comp Immunol Microbiol Infect Dis 2004, 27:343-355 
4. Murgue B, Zeller H, Deubel V: The ecology and epidemiology of West Nile virus in Africa, Europe and Asia. Curr Top Microbiol Immunol 2002, 267:195-221.

5. van der Meulen KM, Pensaert MB, Nauwynck HJ: West Nile virus in the vertebrate world. Arch Virol 2005, 150:637-657.

6. Bakonyi T, Ivanics T, Erdelyi K, Ursu K, Ferenczi E, Weissenbock H, Nowotny $\mathrm{N}$ : Lineage 1 and 2 strains of encephalitic West Nile virus, central Europe. Emerg Infect Dis 2006, 12:618-623.

7. Hofle U, Blanco JM, Crespo E, Naranjo V, Jimenez-Clavero MA, Sanchez A, la Fuente J, Gortazar C: West Nile virus in the endangered Spanish imperial eagle. Vet Microbiol 2008, 129:171-178.

8. Jimenez-Clavero MA, Sotelo E, Fernandez-Pinero J, Llorente F, Manuel Blanco J, Rodriguez-Ramos J, Perez-Ramirez E, Hofle U: West Nile virus in golden eagles, Spain, 2007. Emerg Infect Dis 2008, 14:1489-1491.

9. LaDeau SL, Kilpatrick AM, Marra PP: West Nile virus emergence and largescale declines of North American bird populations. Nature 2007 447:710-713.

10. Centers for Disease Control and Prevention (CDC). [http://www.cdc.gov/ ncidod/dvbid/westnile/index.htm]

11. Brinton MA: The molecular biology of West Nile Virus: a new invader of the western hemisphere. Annu Rev Microbiol 2002, 56:371-402.

12. Deubel V, Fiette L, Gounon P, Drouet MT, Khun H, Huerre M, Banet C, Malkinson M, Despres P: Variations in biological features of West Nile viruses. Ann N Y Acad Sci 2001, 951:195-206.

13. Lindenbach BD, Rice CM: Molecular biology of flaviviruses. Adv Virus Res 2003, 59:23-61.

14. Mackenzie JS, Williams DT: The zoonotic flaviviruses of southern, southeastern and eastern Asia, and Australasia: the potential for emergent viruses. Zoonoses Public Health 2009, 56:338-356.

15. Charrel RN, Brault AC, Gallian P, Lemasson JJ, Murgue B, Murri S, Pastorino B, Zeller $\mathrm{H}$, de Chesse R, de Micco P, de Lamballerie X: Evolutionary relationship between Old World West Nile virus strains. Evidence for viral gene flow between Africa, the Middle East, and Europe. Virology 2003, 315:381-388

16. Lanciotti RS, Ebel GD, Deubel V, Kerst AJ, Murri S, Meyer R, Bowen M, McKinney N, Morrill WE, Crabtree MB, Kramer LD, Roehrig JT: Complete genome sequences and phylogenetic analysis of West Nile virus strains isolated from the United States, Europe, and the Middle East. Virology 2002, 298:96-105.

17. Papa A, Xanthopoulou K, Gewehr S, Mourelatos S: Detection of West Nile virus lineage 2 in mosquitoes during a human outbreak in Greece. Clin Microbiol Infect 2011, 17:1176-1180.

18. Savini G, Capelli G, Monaco F, Polci A, Russo F, Di Gennaro A, Marini V, Teodori L, Montarsi F, Pinoni C, Pisciella M, Terregino C, Marangon S, Capua I, Lelli R: Evidence of West Nile virus lineage 2 circulation in Northern Italy. Vet Microbiol 2012, 158:267-273.

19. Valiakos G, Touloudi A, lacovakis C, Athanasiou L, Birtsas P, Spyrou V, Billinis $C:$ Molecular detection and phylogenetic analysis of West Nile virus lineage 2 in sedentary wild birds (Eurasian magpie), Greece, 2010. Euro Surveill 2011, 16(18):19862. May 5.

20. Wodak E, Richter S, Bago Z, Revilla-Fernandez S, Weissenboeck H, Nowotny $N$, Winter P: Detection and molecular analysis of West Nile virus infections in birds of prey in the eastern part of Austria in 2008 and 2009. Vet Microbiol 2011, 149:358-366.

21. Brault AC, Huang CYH, Langevin SA, Kinney RM, Bowen RA, Ramey WN, Panella NA, Holmes EC, Powers AM, Miller BR: A single positively selected West Nile viral mutation confers increased virogenesis in American crows. Nat Genet 2007, 39:1162-1166.

22. McMullen AR, Albayrak H, May FJ, Davis CT, Beasley DW, Barrett AD: Molecular evolution of lineage 2 West Nile virus. J Gen Virol 2013, 94:318-325

23. Papa A, Bakonyi T, Xanthopoulou K, Vazquez A, Tenorio A, Nowotny N: Genetic characterization of West Nile virus lineage 2, Greece, 2010. Emerg Infect Dis 2011, 17:920-922.

24. Sotelo E, Fernandez-Pinero J, Llorente F, Aguero M, Hoefle U, Blanco JM, Jimenez-Clavero MA: Characterization of West Nile virus isolates from Spain: new insights into the distinct West Nile virus eco-epidemiology in the Western Mediterranean. Virology 2009, 395:289-297.

25. Glavits R, Ferenczi E, Ivanics E, Bakonyi T, Mato T, Zarka P, Palya V: Cooccurrence of West Nile Fever and circovirus infection in a goose flock in Hungary. Avian Pathol 2005, 34:408-414.
26. Erdelyi K, Ursu K, Ferenczi E, Szeredi L, Ratz F, Skare J, Bakonyi T: Clinical and pathologic features of lineage 2 West Nile virus infections in birds of prey in Hungary. Vector Borne Zoonot Dis 2007, 7:181-188.

27. Jourdain E, Schuffenecker I, Korimbocus J, Reynard S, Murri S, Kayser Y, Gauthier-Clerc M, Sabatier P, Zeller HG: West Nile virus in wild resident birds, Southern France, 2004. Vector Borne Zoonot Dis 2007, 7:766-771.

28. Department for Environment Food and Rural Affairs (Defra). [http://archive. defra.gov.uk/foodfarm/farmanimal/diseases/monitoring/documents/wnvaustria.pdf]

29. Monaco F, Lelli R, Teodori L, Pinoni C, Di Gennaro A, Polci A, Calistri P, Savini G: Re-emergence of West Nile virus in Italy. Zoonoses Public Health 2010, 57:476-486.

30. Savini G, Puggioni G, DI Gennaro A, DI Francesco G, Rocchigiani AM, Polci A, Marini V, Pinoni C, Rolesu S, Marruchella G, Lorusso A, Monaco F: West Nile virus lineage 2 in Sardinian wild birds in 2012: a further threat to public health. Epidemiol Infect 2013:1-4

31. Hubalek Z, Halouzka J: West Nile fever - a reemerging mosquito-borne viral disease in Europe. Emerg Infect Dis 1999, 5:643-650.

32. Jourdain E, Gauthier-Clerc M, Bicout DJ, Sabatier P: Bird migration routes and risk for pathogen dispersion into western Mediterranean wetlands. Emerg Infect Dis 2007, 13:365-372.

33. Malkinson M, Banet C: The role of birds in the ecology of West Nile virus in Europe and Africa. Curr Top Microbiol Immunol 2002, 267:309-322.

34. Peterson AT, Vieglais DA, Andreasen JK: Migratory birds modeled as critical transport agents for West Nile Virus in North America. Vector Borne Zoonot Dis 2003, 3:27-37.

35. Rappole JH, Compton BW, Leimgruber P, Robertson J, King DI, Renner SC: Modeling movement of West Nile virus in the western hemisphere. Vector Borne Zoonot Dis 2006, 6:128-139.

36. Komar N, Langevin S, Hinten S, Nemeth N, Edwards E, Hettler D, Davis B, Bowen R, Bunning M: Experimental infection of North American birds with the New York 1999 strain of West Nile virus. Emerg Infect Dis 2003, 9:311-322.

37. Kilpatrick AM, Daszak P, Jones MJ, Marra PP, Kramer LD: Host heterogeneity dominates West Nile virus transmission. Proc Biol SCi 2006, 273:2327-2333.

38. Langevin SA, Brault AC, Panella NA, Bowen RA, Komar N: Variation in virulence of West Nile virus strains for house sparrows (Passer domesticus). Am J Trop Med Hyg 2005, 72:99-102.

39. Kramer LD, Styer LM, Ebel GD: A global perspective on the epidemiology of West Nile virus. Annu Rev Entomol 2008, 53:61-81.

40. Banet-Noach C, Simanov L, Malkinson M: Direct (non-vector) transmission of West Nile virus in geese. Avian Pathol 2003, 32:489-494.

41. Langevin SA, Bunning M, Davis B, Komar N: Experimental infection of chickens as candidate sentinels for West Nile virus. Emerg Infect Dis 2001, 7:726-729.

42. Nemeth N, Gould D, Bowen R, Komar N: Natural and experimental West Nile virus infection in five raptor species. J Wildl Dis 2006, 42:1-13.

43. Swayne DE, Beck JR, Smith CS, Shieh WJ, Zaki SR: Fatal encephalitis and myocarditis in young domestic geese (Anser anser domesticus) caused by West Nile virus. Emerg Infect Dis 2001, 7:751-753.

44. Jimenez-Clavero MA: Animal viral diseases and global change: bluetongue and West Nile fever as paradigms. Front Genet 2012, 3:105.

45. Phalen DN, Dahlhausen B: West Nile virus. Semin Avian Exot Pet Med 2004, 13:67-78.

46. Work TH, Hurlbut HS, Taylor RM: Indigenous wild birds of the Nile Delta as potential West Nile virus circulating reservoirs. Am J Trop Med Hyg 1955, 4:872-888.

47. Zeller HG, Schuffenecker I: West Nile virus: An overview of its spread in europe and the Mediterranean Basin in contrast to its spread in the Americas. Eur J Clin Microbiol Infect Dis 2004, 23:147-156.

48. Malkinson M, Banet C, Weisman Y, Pokamunski S, King R, Drouet MT, Deubel $\checkmark$ : Introduction of West Nile virus in the Middle East by migrating white storks. Emerg Infect Dis 2002, 8:392-397.

49. Lanciotti RS, Roehrig JT, Deubel V, Smith J, Parker M, Steele K, Crise B, Volpe KE, Crabtree MB, Scherret JH, Hall RA, MacKenzie JS, Cropp CB, Panigrahy B, Ostlund E, Schmitt B, Malkinson M, Banet C, Weissman J, Komar N, Savage HM, Stone W, McNamara T, Gubler DJ: Origin of the West Nile virus responsible for an outbreak of encephalitis in the northeastern United States. Science 1999, 286:2333-2337. 
50. Centers for Disease Control and Prevention (CDC). [http://www.cdc.gov/ ncidod/dvbid/westnile/birdspecies.htm]

51. De Filette M, Ulbert S, Diamond M, Sanders NN: Recent progress in West Nile virus diagnosis and vaccination. Vet Res 2012, 43:16

52. Brinton MA: Host factors involved in West Nile virus replication. Ann N Y Acad Sci 2001, 951:207-219.

53. Ezenwa VO, Godsey MS, King RJ, Guptill SC: Avian diversity and West Nile virus: testing associations between biodiversity and infectious disease risk. Proc Biol Sci 2006, 273:109-117.

54. Hamer GL, Kitron UD, Goldberg TL, Brawn JD, Loss SR, Ruiz MO, Hayes DB, Walker ED: Host selection by Culex pipiens mosquitoes and West Nile virus amplification. Am J Trop Med Hyg 2009, 80:268-278.

55. Ostfeld RS, Keesing F: The function of biodiversity in the ecology of vector-borne zoonotic diseases. Can J Zool 2000, 78:2061-2078.

56. Fang Y, Reisen WK: Previous infection with West Nile or St. Louis encephalitis viruses provides cross protection during reinfection in house finches. Am J Trop Med Hyg 2006, 75:480-485.

57. Figuerola J, Jimenez-Clavero MA, Lopez G, Rubio C, Soriguer R, GomezTejedor C, Tenorio A: Size matters: West Nile Virus neutralizing antibodies in resident and migratory birds in Spain. Vet Microbiol 2008, 132:39-46.

58. Gancz AY, Barker IK, Lindsay R, Dibernardo A, McKeever K, Hunter B: West Nile virus outbreak in North American owls, Ontario, 2002. Emerg Infect Dis 2004, 10:2135-2142.

59. Kwan JL, Kluh S, Reisen WK: Antecedent avian immunity limits tangential transmission of West Nile virus to humans. PLoS One 2012, 7:e34127.

60. Reisen WK, Hahn DC: Comparison of immune responses of brownheaded cowbird and related blackbirds to west Nile and other mosquito-borne encephalitis viruses. J Wildl Dis 2007, 43:439-449.

61. Samuel MA, Diamond MS: Pathogenesis of West Nile virus infection: a balance between virulence, innate and adaptive immunity, and viral evasion. J Virol 2006, 80:9349-9360.

62. Nemeth NM, Thomsen BV, Spraker TR, Benson JM, Bosco-Lauth AM, Oesterle PT, Bright JM, Muth JP, Campbell TW, Gidlewski TL, Bowen RA: Clinical and pathologic responses of American crows (Corvus brachyrhynchos) and fish crows (C ossifragus) to experimental west nile virus Infection. Vet Pathol 2011, 48:1061-1074.

63. Reisen $W K$, Fang $Y$, Martinez $V$ : Is nonviremic transmission of West Nile virus by Culex mosquitoes (Diptera: Culicidae) nonviremic? J Med Entomol 2007, 44:299-302.

64. Weingartl HM, Neufeld JL, Copps J, Marszal P: Experimental west nile virus infection in blue jays (Cyanocitta cristata) and crows (Corvus brachyrhynchos). Vet Pathol 2004, 41:362-370.

65. Senne DA, Pedersen JC, Hutto DL, Taylor WD, Schmitt BJ, Panigrahy B: Pathogenicity of West Nile virus in chickens. Avian Dis 2000 44:642-649.

66. Nemeth NM, Hahn DC, Gould DH, Bowen RA: Experimental West Nile virus infection in Eastern Screech Owls (Megascops asio). Avian Dis 2006, 50:252-258

67. Ziegler U, Angenvoort J, Fischer D, Fast C, Eiden M, Rodriguez AV, Revilla-Fernandez S, Nowotny N, de la Fuente JG, Lierz M, Groschup $\mathrm{MH}$ : Pathogenesis of West Nile virus lineage 1 and 2 in experimentally infected large falcons. Vet Microbiol 2013, 161:263-273.

68. Lapointe DA, Hofmeister EK, Atkinson CT, Porter RE, Dusek RJ: Experimental infection of Hawai'i 'Amakihi (hemignathus virens) with West Nile virus and competence of a co-occurring vector, culex quinquefasciatus: potential impacts on endemic Hawaiian avifauna. J Wildl Dis 2009, 45:257-271.

69. Swayne DE, Beck JR, Zaki S: Pathogenicity of West Nile virus for turkeys. Avian Dis 2000, 44:932-937.

70. Suthar MS, Diamond MS, Gale M Jr: West Nile virus infection and immunity. Nat Rev Microbiol 2013, 11:115-128.

71. Steele KE, Linn MJ, Schoepp RJ, Komar N, Geisbert TW, Manduca RM, Calle PP, Raphael BL, Clippinger TL, Larsen T, Smith J, Lanciotti RS, Panella NA, McNamara TS: Pathology of fatal West Nile virus infections in native and exotic birds during the 1999 outbreak in New York City, New York. Vet Pathol 2000, 37:208-224.

72. Busquets N, Bertran K, Costa TP, Rivas R, de la Fuente JG, Villalba R, Solanes $D$, Bensaid A, Majo N, Pages N: Experimental West Nile virus infection in Gyr-Saker hybrid falcons. Vector Borne Zoonotic Dis 2012, 12:482-489.

73. Ye J, Zhu B, Fu ZF, Chen H, Cao S: Immune evasion strategies of flaviviruses. Vaccine 2013, 31:461-471.
74. Wang T, Town T, Alexopoulou L, Anderson JF, Fikrig E, Flavell RA: Toll-like receptor 3 mediates West Nile virus entry into the brain causing lethal encephalitis. Nat Med 2004, 10:1366-1373.

75. McMinn PC: The molecular basis of virulence of the encephalitogenic flaviviruses. J Gen Virol 1997, 78:2711-2722.

76. Monath TP, Cropp CB, Harrison AK: Mode of entry of a neurotropic arbovirus into the central nervous system. Reinvestigation of an old controversy. Lab Investig 1983, 48:399-410.

77. Samuel MA, Wang H, Siddharthan V, Morrey JD, Diamond MS: Axonal transport mediates West Nile virus entry into the central nervous system and induces acute flaccid paralysis. Proc Natl Acad Sci U S A 2007, 104:17140-17145.

78. Garcia-Tapia D, Loiacono CM, Klelboeker SB: Replication of West Nile virus in equine peripheral blood mononuclear cells. Vet Immunol Immunopathol 2006, 110:229-244.

79. Lopes H, Redig P, Glaser A, Armien A, Wunschmann A: Clinical findings, lesions, and viral antigen distribution in great gray owls (Strix nebulosa) and barred owls (Strix varia) with spontaneous West Nile virus infection. Avian Dis 2007, 51:140-145.

80. Wunschmann A, Shivers J, Carroll L, Bender J: Pathological and immunohistochemical findings in American crows (Corvus brachyrhynchos) naturally infected with West Nile virus. J Vet Diag Invest 2004, 16:329-333.

81. Bertelsen MF, Olberg RA, Crawshaw GJ, Dibernardo A, Lindsay LR, Drebot M, Barker IK: West Nile virus infection in the eastern loggerhead shrike (Lanius ludovicianus migrans): Pathology, epidemiology, and immunization. J Wildl Dis 2004, 40:538-542.

82. Fitzgerald SD, Patterson JS, Kiupel M, Simmons HA, Grimes SD, Sarver CE, Fulton RM, Steficek BA, Cooley TM, Massey JP, Sikarskie JG: Clinical and pathologic features of West Nile virus infection in native North American owls (Family strigidae). Avian Dis 2003, 47:602-610.

83. Wunschmann A, Ziegler A: West Nile virus-associated mortality events in domestic chukar partridges (Alectoris chukar) and domestic Impeyan pheasants (Lophophorus impeyanus). Avian Dis 2006, 50:456-459.

84. Sotelo E, Gutierrez-Guzman AV, del Amo J, Llorente F, El-Harrak M, Perez Ramirez E, Manuel Blanco J, Hoefle U, Angel Jimenez-Clavero M: Pathogenicity of two recent Western Mediterranean West Nile virus isolates in a wild bird species indigenous to Southern Europe: the redlegged partridge. Vet Res 2011, 42:11.

85. D'Agostino JJ, Isaza R: Clinical signs and results of specific diagnostic testing among captive birds housed at zoological institutions and infected with West Nile virus. J Am Vet Med Assoc 2004, 224:1640-1643.

86. Joyner PH, Kelly S, Shreve AA, Snead SE, Sleeman JM, Pettit DA: West Nile virus in raptors from Virginia during 2003: clinical, diagnostic, and epidemiologic findings. J Wild Dis 2006, 42:335-344.

87. Palmieri C, Franca M, Uzal F, Anderson M, Barr B, Woods L, Moore J, Woolcock P, Shivaprasad HL: Pathology and immunohistochemical findings of West Nile virus infection in psittaciformes. Vet Pathol 2011, 48:975-984

88. Saito EK, Sileo L, Green DE, Meteyer CU, McLaughlin GS, Converse KA, Docherty DE: Raptor mortality due to West Nile virus in the United States, 2002. J Wildl Dis 2007, 43:206-213.

89. Wunschmann A, Shivers J, Bender J, Carroll L, Fuller S, Saggese M, van Wettere A, Redig P: Pathologic findings in red-tailed hawks (Buteo jamaicensis) and Cooper's hawks (Accipiter cooperi) naturally infected with West Nile virus. Avian Dis 2004, 48:570-580.

90. Gancz AY, Smith DA, Barker IK, Lindsay R, Hunter B: Pathology and tissue distribution of West Nile virus in North American owls (family : Strigidae). Avian Pathol 2006, 35:17-29.

91. Wunschmann A, Shivers J, Bender J, Carroll L, Fuller S, Saggese M, van Wettere A, Redig P: Pathologic and immunohistochemical findings in goshawks (Accipiter gentilis) and great horned owls (Bubo virginianus) naturally infected with West Nile virus. Avian Dis 2005, 49:252-259.

92. Nemeth NM, Kratz GE, Bates R, Scherpelz JA, Bowen RA, Komar N: Clinical evaluation and outcomes of naturally acquired West Nile virus infection in raptors. J Zoo Wild Med 2009, 40:51-63.

93. Gibbs SEJ, Hoffman DM, Stark LM, Marlenee NL, Blitvich BJ, Beaty BJ, Stallknecht DE: Persistence of antibodies to West Nile virus in naturally infected rock pigeons (Columba livia). Clin Diagn Lab Immunol 2005, 12:665-667. 
94. Hahn DC, Nemeth NM, Edwards E, Bright PR, Komar N: Passive West Nile virus antibody transfer from maternal Eastern Screech-Owls (Megascops asio) to progeny. Avian Dis 2006, 50:454-455.

95. Nemeth NM, Oesterle PT, Bowen RA: Humoral Immunity to West Nile virus Is long lasting and protective in the house sparrow (Passer domesticus). Am J Trop Med Hyg 2009, 80:864-869.

96. Wilcox BR, Yabsley MJ, Ellis AE, Stallknecht DE, Gibbs SEJ: West Nile virus antibody prevalence in American crows (Corvus brachyrhynchos) and fish crows (Corvus ossifragus) in Georgia, USA. Avian Dis 2007 51:125-128.

97. Lobigs M, Müllbacher A, Regner M: CD4+ and CD8+ T-Cell Immune Responses in West Nile Virus Infection. In West Nile Encephalitis Virus Infection. Edited by Diamond MS. New York: Springer Science+Business Media; 2009:287-307

98. Wheeler SS, Langevin SA, Brault AC, Woods L, Carroll BD, Reisen WK: Detection of persistent West Nile virus RNA in experimentally and naturally infected avian hosts. Am J Trop Med Hyg 2012, 87:559-564.

99. Nemeth N, Young G, Ndaluka C, Bielefeldt-Ohmann H, Komar N, Bowen R: Persistent West Nile virus infection in the house sparrow (Passer domesticus). Arch Virol 2009, 154:783-789.

100. Wheeler SS, Vineyard MP, Woods LW, Reisen WK: Dynamics of West Nile virus persistence in House Sparrows (Passer domesticus). PLoS Negl Trop Dis 2012, 6:e1860.

101. Reisen WK, Fang Y, Lothrop HD, Martinez VM, Wilson J, Oconnor P, Carney R, Cahoon-Young B, Shafii M, Brault AC: Overwintering of West Nile virus in Southern California. J Med Entomol 2006, 43:344-355.

102. Semenov BF, Chunikhin SP, Karmysheva V, lakovleva NI: Study of chronic forms of arbovirus infections in birds. 1. Experiments with West Nile, Sindbis, Bhandja and Sicilian mosquito fever viruses. Vestn Akad Med Nauk SSSR 1973, 28:79-83.

103. Wheeler SS, Vineyard MP, Barker CM, Reisen WK: Importance of recrudescent avian infection in West Nile virus overwintering: incomplete antibody neutralization of virus allows infrequent vector infection. J Med Entomol 2012, 49:895-902.

104. Shirato K, Miyoshi H, Goto A, Ako Y, Ueki T, Kariwa H, Takashima I: Viral envelope protein glycosylation is a molecular determinant of the neuroinvasiveness of the New York strain of West Nile virus. J Gen Virol 2004, 85:3637-3645.

105. Murata R, Eshita Y, Maeda A, Maeda J, Akita S, Tanaka T, Yoshii K, Kariwa H, Umemura T, Takashima I: Glycosylation of the West Nile Virus envelope protein increases in vivo and in vitro viral multiplication in birds. Am J Trop Med Hyg 2010, 82:696-704.

106. Papa A, Danis K, Baka A, Bakas A, Dougas G, Lytras T, Theocharopoulos G, Chrysagis D, Vassiliadou E, Kamaria F, Liona A, Mellou K, Saroglou G, Panagiotopoulos T: Ongoing outbreak of West Nile virus infections in humans in Greece, July - August 2010. Euro Surveill 2010, 15:pii:19644.

107. Botha EM, Markotter W, Wolfaardt M, Paweska JT, Swanepoel R, Palacios G, Nel LH, Venter M: Genetic determinants of virulence in pathogenic lineage 2 West Nile virus strains. Emerg Infect Dis 2008 $14: 222-230$

108. Kinney RM, Huang CY, Whiteman MC, Bowen RA, Langevin SA, Miller BR, Brault AC: Avian virulence and thermostable replication of the North American strain of West Nile virus. J Gen Virol 2006, 87:3611-3622.

109. Eldadah AH, Nathanso N, Sarsitis R: Pathogenesis of West Nile Virus encephalitis in mice and mats. I. Influence of age and species on mortality and infection. Am J Epidemiol 1967, 86:765-775.

110. Nemeth NM, Bowen RA: Dynamics of passive immunity to West Nile virus in domestic chickens (Gallus gallus domesticus). Am J Trop Med Hyg 2007, 76:310-317

111. Nemeth NM, Kratz GE, Bates R, Scherpelz JA, Bowen RA, Komar N: Naturally induced humoral immunity to West Nile virus infection in raptors. Ecohealth 2008, 5:298-304.

112. Shirafuji $H$, Kanehira K, Kubo M, Shibahara T, Kamio T: Experimental West Nile virus infection in aigamo ducks, a cross between wild ducks (Anas platyrhynchos) and domestic ducks (Anas platyrhynchos var. domesticus). Avian Dis 2009, 53:239-244.

113. Chambers TJ, Diamond MS: Pathogenesis of flavivirus encephalitis. Adv Virus Res 2003, 60:273-342.

114. Sangster MY, Urosevic N, Mansfield JP, Mackenzie JS, Shellam GR: Mapping the Flv locus controlling resistance to flaviviruses on mouse chromosome 5. J Virol 1994, 68:448-452.
115. Tag-El-Din-Hassan HT, Sasaki N, Moritoh K, Torigoe D, Maeda A, Agui T: The chicken 2'-5' oligoadenylate synthetase $A$ inhibits the replication of West Nile virus. Jpn J Vet Res 2012, 60:95-103.

116. Lim SM, Koraka P, Osterhaus AD, Martina BE: West Nile virus: immunity and pathogenesis. Viruses 2011, 3:811-828

117. Pauli AM, Cruz-Martinez LA, Ponder JB, Redig PT, Glaser AL, Klauss G Schoster JV, Wunschmann A: Ophthalmologic and oculopathologic findings in red-tailed hawks and Cooper's hawks with naturally acquired West Nile virus infection. J Am Vet Med Assoc 2007, 231:1240-1248.

118. Gibbs SE, Ellis AE, Mead DG, Allison AB, Moulton JK, Howerth EW, Stallknecht DE: West Nile virus detection in the organs of naturally infected blue jays (Cyanocitta cristata). J Wildl Dis 2005, 41:354-362.

119. Ellis $A E$, Mead DG, Allison AB, Stallknecht DE, Howerth EW: Pathology and epidemiology of natural West Nile viral infection of raptors in Georgia. J Wildl Dis 2007, 43:214-223.

120. Ernest HB, Woods LW, Hoar BR: Pathology associated with West Nile virus infections in the yellow-billed magpie (Pica nuttalli): a California endemic bird. J Wildl Dis 2010, 46:401-408.

121. O'Brien VA, Meteyer CU, Reisen WK, Ip HS, Brown CR: Prevalence and pathology of West Nile virus in naturally infected house sparrows, western Nebraska, 2008. Am J Trop Med Hyg 2010, 82:937-944.

122. Zhang Z, Wilson F, Read R, Pace L, Zhang S: Detection and characterization of naturally acquired West Nile virus infection in a female wild turkey. J Vet Diag Invest 2006, 18:204-208.

123. Stockman J, Hawkins MG, Burns RE, Fang Y, Brault AC, Lowenstine LJ: West Nile virus infection in a green-winged macaw (Ara chloropterus). Avian Dis 2010, 54:164-169.

124. Himsworth CG, Gurney KEB, Neimanis AS, Wobeser GA, Leighton FA: An outbreak of West Nile virus infection in captive lesser scaup (Aythya affinis) ducklings. Avian Dis 2009, 53:129-134.

125. Foppa IM, Beard RH, Mendenhall IH: The impact of West Nile virus on the abundance of selected North American birds. Vet Res 2011, 7:43.

126. Nash D, Mostashari F, Fine A, Miller J, O'Leary D, Murray K, Huang A, Rosenberg A, Greenberg A, Sherman M, Wong S, Layton M, Campbell GL, Roehrig JT, Gubler DJ, Shieh WJ, Zaki S, Smith P, Working WNOR: The outbreak of West Nile virus infection in the New York City area in 1999. N Engl J Med 2001, 344:1807-1814.

127. Paddock CD, Nicholson WL, Bhatnagar J, Goldsmith CS, Greer PW, Hayes EB, Risko JA, Henderson C, Blackmore CG, Lanciotti RS, Campbell GL, Zaki SR: Fatal hemorrhagic fever caused by West Nile virus in the United States. Clin Infect Dis 2006, 42:1527-1535.

128. Barker WC, Mazumder R, Vasudevan S, Sagripanti J-L, Wu CH: Sequence signatures in envelope protein may determine whether flaviviruses produce hemorrhagic or encephalitic syndromes. Virus Genes 2009, 39:1-9.

129. Cork SC, Alley MR, Stockdale PH: A quantitative assesment of hemosiderosis in wild and captive birds using image-analysis. Avian Pathol 1995, 24:239-254.

\section{doi:10.1186/1297-9716-44-39}

Cite this article as: Gamino and Höfle: Pathology and tissue tropism of natural West Nile virus infection in birds: a review. Veterinary Research 2013 44:39.

\section{Submit your next manuscript to BioMed Central and take full advantage of:}

- Convenient online submission

- Thorough peer review

- No space constraints or color figure charges

- Immediate publication on acceptance

- Inclusion in PubMed, CAS, Scopus and Google Scholar

- Research which is freely available for redistribution 